Article

\title{
THE REMAKING OF LEVIATHAN: THE STATE AND PUBLIC SECTOR REFORM IN ADVANCED CAPITALIST COUNTRIES
}

\author{
JOHN PETERS \\ Department of Political Science, Laurentian University. \\ Sudbury, Canada. ${ }^{1}$
}

\begin{abstract}
This article argues that recent comparatives literatures on the welfare state have yet to adequately consider the public sector and how governments have reshaped their public services. Drawing on macrolevel data from the OECD, qualitative studies, and trade union research, it is claimed that governments have substantially remade their administrative and financial procedures in order to cut expenditures and lower labour costs. It is also contended that because of financial globalization and rising debt, states have made a series of reforms to public sector industrial relations. These have worsened wages, working conditions, and jobs throughout the public sector. It is concluded that such developments are central to reforming the nature of state functioning across North America and Western Europe. This is the first study to report on government reforms to fiscal policies, public sector services, and public sector labour forces in 13 OECD countries between 1980-2005.
\end{abstract}

\section{Résumé}

Cet article avance que les récentes recherches comparatives sur l'Étatprovidence ne considèrent pas encore de manière adéquate le secteur public et comment les gouvernements ont restructuré les services

\footnotetext{
${ }^{1}$ Dr. John Peters is an assistant professor of political science at Laurentian University, Sudbury Ontario Canada. He is one of the general editors of the 'Labour in Canada' series and the forthcoming collection Boom, Bust, and Crisis: Work and Labour in 21st Century Canada (Fall 2011, Fernwood Publishing). His recently accepted publications include 'The Rise of Finance and the Decline of Organized Labour in Advanced Capitalist Countries' New Political Economy Vol. 16 no. 1 2011; and 'Down in the Vale: Corporate Globalization, Unions on the Defensive, and the USW Local 6500 Strike in Sudbury, 2009-2010' Labour/Le Travail Vol. 66 Fall 2010. He is currently completing a study on the impacts of globalization on labor movements and public policy in North America and Western Europe.
} 
publics. A partir de données macro de l'OCDE, d'études qualitatives et de recherches faites par des syndicats, cet article explique que les gouvernements ont revu de façon substantielle leurs procédures administratives et financières afin de couper leurs dépenses et de réduire les coûts du travail. II est aussi avancé qu'à cause de la globalisation financière et de l'augmentation de la dette, les États ont engagé une série de réformes dans les relations de travail du secteur public. Ceci a aggravé les salaires, les conditions de travail et les emplois à travers le secteur public. L'article conclue que de tels développements sont centraux à la réforme de la nature du fonctionnement de l'État en Amérique du Nord et en Europe de l'Ouest. C'est la première étude qui analyse les réformes gouvernementales dans les politiques fiscales, les services publics et les employés du secteur public dans 13 pays de l'OCDE entre 1980 et 2005.

\section{Acknowledgements}

The author would like to thank Anick Yaha-Sian for her invaluable research assistance, as well as thank Laurentian University for research funding. This paper benefited from comments by Angela Carter, Bryan Evans, Christoph Hermann, Stephen Hellman, and two anonymous reviewers.

\section{Keywords}

labour policy, public administration, labour unions, public welfare, inequality

\section{Mots-clés}

politique du travail, administration publique, syndicats, bien-être public, inégalités.

To many, the recent global crisis has been the midwife for the return of 'Leviathan' - of 'big government' that interferes with markets and economic efficiency. Government public spending is up, in some cases by more than 7 percent of GDP, and now most government's total spending exceeds 40 percent of GDP. Governments have bailed out banks on an unprecedented scale, while injecting trillions of dollars of liquidity into their economies. In the United States, the American government is largely in charge of General Motors; in Britain, government is overseeing high street banks. On top of this, governments threaten to take more action to regulate their banks, while also making noise to regulate carbon emissions from factories and introduce greater energy efficiency. For Nicholas Sarkozy, who has tried to take a leadership role and seriously consider alternatives, what all this has meant is the 'return of the state'. For business publications 
such as the economist, these are ominous signs of a foreboding new era of 'big government' (Economist 2010).

But a question little asked is 'what kind of 'big government'? Because throughout the past twenty five years, advanced industrial governments have made substantive reforms. Today, the private sector - because of privatisation and contracting out provides more than 40 percent of public goods (OECD 2009). Public sector reforms have led to the widespread introduction of market competition throughout departments and agencies. There has also been a major shift away from public forms of social protection to new privately-financed and privately-provided social insurance. Tax cuts have been deep. Tax subsidies - to business as well as to the wealthy and middle classes for capital investment and private purchase of insurance and services - have been just as extensive. In a longer-term perspective, this seems less a return of 'big' government than a return to older liberal models of capitalism - state support for business, free trade, open finance, ever greater restrictions on social and labour rights, and at the same time the a multitrillion dollar bailout of finance paid for by workers and citizens.

Over the past ten years, many scholarly studies have overlooked these rapid transformations and instead emphasised the slow changing nature of states - how welfare states are resilient, how institutions create rules that regularise behaviour, and how domestic interests defend existing institutions in the face of global economic pressures (Castles 2004; Martin and Thelen 2007; Pontusson 2005). One of the key suppositions is that left political parties, unions, and the depth of corporatist and collective bargaining systems, influence economic and social policy reform, and that governments respond to public demand for compensatory social policies (Huber and Stephens 2001; Swank 2002). Also widely held is the notion that levels of public consumption are likely to be determined less by the extent of need and available resources than by popular views of what is considered appropriate, and by how political parties look to support core constituencies with appropriate social policies (Beramendi and Cusack 2008; Cusack, Iverson, and Rehm 2008; Pierson 2001; Garrett 1998). In these literatures, only in periods of crisis does change take place, and it does so in ways moulded by existing institutions, politics, and organized interests demands for security and state support.

However, if scholars have paid close attention to the effects of economic change on welfare states as well at how states have reshaped economic environments to promote globalization (Schmidt 2008; Levy 2006), the issues of public sector restructuring and the political consequences of public policy reform have received relatively little attention from social scientists. This relative lack of attention by comparative scholars to the questions of public services and the recent impacts of public service reform on labour markets and politics is surprising given the importance governments have attached to 'modernizing' government and reshaping public services over the last twenty years (OECD 2009; OECD 2008; OECD 2003). The inattention is also surprising as governments have long been the single largest employer in all countries, and public 
service employment has been a key means for stabilizing jobs and incomes as well as ensuring equality (Schulten, Brandt, and Hermann 2008; Lee 2005; OECD 2008). The changes in public sectors have also been profound, and have often converged around common supply-side and market oriented measures of new public management and privatization.

In Great Britain, Gerry Mooney and Alex Law (2007) have begun to undertake some of this research, demonstrating the impacts of public service change on British workers involved in service delivery, showing how wages have fallen, workloads increased, and job quality worsened. Other critical scholars in Great Britain have examined the negative impacts of privatization and marketization on service quality, employment, collective bargaining, and costs to citizens (Hall 2005; Hall and Lethbridge 2006; Pollock and Leys 2004; Whitfield 2011). However, if British literatures have begun to move these debates forward, existing comparative welfare research has not yet analyzed these reversals in public sector services and employment, instead focusing primarily on spending, governance, and policy reform. The most recent current of welfare state research on 'Dualisation' has added to our knowledge about public policy changes and their political causes and political impacts by exploring how mean-testing and private provision arrangements are institutionalizing economic inequality throughout Western Europe (Davidsson and Naczyk 2009; Palier and Thelen 2010;). But it too says little about how public employment and public sector collective bargaining arrangements have themselves been overhauled and reworked as part of broader trends intended to lower labour costs.

Looking to develop a better understanding of what has happened to states and the public sector, the goal of this article is to go beyond conventional institutional perspectives on the static nature of states and instead provide an assessment of what has happened to fiscal policy and public administration since the early 1980s and then examine their impacts on organized labour and labour markets. Drawing on recent case study and trade union research, it is argued that over the past two decades, states have taken active roles in remaking their public sectors either directly through outsourcing or more generally by modeling them along the lines of private business throughout North America and Western Europe (Bordogna 2008; Brandt and Schulten 2009; Flecker et al. 2009; Leys 2003; Pedersini 1999; Whitfield 2001).

Contrary to standard comparative literatures, I argue that major changes have indeed taken place to public sector management and operation in many countries regardless of political and institutional setup, corporatism, or higher levels of public sector spending. Even if there are powerful political forces that stabilize welfare states and public expenditures, I claim that the pressures of debt and finance, along with significant shifts in domestic politics to the right have led states to lower labour costs and shift their public sectors away from considerations of need and towards priorities that are set by economics and market models. These shifts in politics and policy have had a negative 
impact on the public service for one primary reason - states as employers have changed. Consequently, it has become much more common for governments to pursue eliminating deficits and redesigning their public services as key means to reduce spending and lowering labour costs.

Based on macro-level data collected from thirteen OECD countries that are most representative of Nordic and continental European 'social market economies' (SMEs) as well as the Anglo-American 'liberal market economies' (LMEs), (and are conventionally believed to respond to economic and social pressure through dramatically different public policies), this article looks to assess the extent of convergence of public policy reforms around a common set of austerity measures and new public management programmes, and whether they have had common consequences on public sector jobs and incomes. The paper concludes by suggesting that even if there still are wide variations in public sector spending, public sector size, and public service/transfer programmes, the keys to understanding recent changes to these lie less in the impacts of stable institutions and powerful organized constituencies in deflecting economic pressures, and more with states steering among the conflicting pressures of finance, debt, rising inequality, and the declining support for redistribution.

\section{Debt and Public Sector Restructuring}

Over the past decade, a sizable literature has investigated the link between policymaking and business demand for better conditions of profitability and productivity (Dumenil and Levy 2004; Glyn 2006; Harvey 2006). As this work has shown, in the wake of economic slowdown in the 1980s and 1980s, capital sought low inflation, wage restraint and wage flexibility to improve economic growth. Governments sought to facilitate conditions for profitable capital accumulation on the part of both domestic and foreign capital by tightening fiscal policy, reducing taxes, and balancing budgets. Spending cuts were chosen over tax increases as such austerity measures were seen to boost the confidence of business and increase employment. Tax cuts were to spur new investment and in turn provide the economic growth that would underpin government revenue. Reductions in public sector spending were to weaken labour's bargaining power and encourage people to work harder (Whitfield 2001; Panitch and Swartz 2003). 
Table 1 Debt and Reductions in Government Spending

\begin{tabular}{|c|c|c|c|c|c|c|c|c|c|c|}
\hline & \multirow{2}{*}{\multicolumn{5}{|c|}{ Gross Public Debt (as \% of GDP) }} & \multirow{2}{*}{\multicolumn{3}{|c|}{ General Expenditure }} & \multirow{2}{*}{$\begin{array}{l}\text { Public Service } \\
\text { ) }\end{array}$} & \multirow{3}{*}{$\begin{array}{c}\text { Social Protection } \\
1995-2005\end{array}$} \\
\hline & & & & & & & & & & \\
\hline & 1980 & 1990 & 1995 & 2000 & 2005 & 1995 & $2005 \mathrm{C}$ & ange & $1995-2005$ & \\
\hline Austria & 36 & 57.0 & 69.0 & 71.0 & 71.0 & 56.3 & 49.3 & -7 & -2 & -3 \\
\hline Belgium & 75 & 125.5 & 135.0 & 113.0 & 96.0 & 52.1 & 48.4 & -3.7 & -3.8 & -0.8 \\
\hline Canada & 46 & 75.0 & 101.0 & 82.0 & 71.0 & 48.5 & 39.2 & -9.3 & -5.1 & -2 \\
\hline Germany & 31 & 45.5 & 55.6 & 60.0 & 71.0 & 59.2 & 51.2 & -8 & -4.3 & -2.7 \\
\hline Denmark & 44 & 66.0 & 79.0 & 57.0 & 42.0 & 61.6 & 48.9 & -12.7 & -1.3 & -5.4 \\
\hline Finland & 14 & 16.0 & 65.0 & 52.0 & 49.0 & 54.4 & 52.7 & -1.7 & -1.2 & -1.7 \\
\hline France & 30 & 38.5 & 62.5 & 65.5 & 75.6 & 54.8 & 45.4 & -9.3 & -0.7 & -0.5 \\
\hline Italy & 89 & 97.5 & 112.5 & 121.0 & 123.5 & 52.5 & 49.9 & -2.6 & -5.4 & -0.1 \\
\hline Netherlands & 59 & 87.5 & 89.5 & 64.0 & 71.5 & 56.4 & 45.6 & -10.8 & -3 & -4 \\
\hline Norway & 40 & 29.3 & 41.0 & 34.0 & 49.0 & 50.9 & 41.7 & -9.5 & -2.2 & -1.8 \\
\hline Sweden & 47 & 46.0 & 81.0 & 65.0 & 60.0 & 65.1 & 54.3 & -10.8 & -3 & -3.8 \\
\hline United Kingdom & 49 & 32.0 & 51.5 & 45.1 & 46.0 & 44.7 & 44.3 & -0.3 & -1 & -1.5 \\
\hline United States & 41 & 63.0 & 70.5 & 54.5 & 61.0 & 37 & 36.7 & -0.3 & -1.8 & -0.4 \\
\hline Mean & 46.2 & 60 & 78 & 68.0 & 68 & 54.4 & 48.4 & -8 & -2.2 & -1.8 \\
\hline
\end{tabular}

As table 1 confirms, debt rose substantially over the period 1990-2005 for the majority of countries, and rather than increase taxes, governments cut expenditures. Government debt levels rose on average from 44 percent of GDP across these thirteen countries to 60 percent from 1980 to 1990 as economic growth slowed, competition increased, and tax regimes were shifted. Debt then became substantial rising on average another 18 percent to 78 percent of GDP by 1995 with the global recession of the early 1990s. Debt ratios climbed most quickly in Canada, Italy, Belgium, Denmark, and Finland, but also rose substantially in the Austria, France, Germany, the Netherlands, the United States, and Sweden. In the UK, debt followed counter-cyclical swings in the economy, rising quickly in the early 1990s recession. Only Norway, with its expanding oil revenues and oil royalties saw continuing swings in its debt-to-GDP ratios, as resource prices contributed to boom-bust cycles of economic growth.

But the turn to fiscal orthodoxy became much more pronounced over the period 1995-2005, when all governments reduced general spending on average by 8 percent of GDP, and cut expenditures on general public services, social protection, and housing and community programs by 2.2 percent, 1.8 percent, and .1 percent of GDP respectively. Countries as varied as Finland, Sweden, the Netherlands, Canada, Denmark, and Austria made the most substantive cuts to both general spending and spending on public services and social protection. France and Germany undertook more modest reductions. While contrary to expectations, Great Britain and the United States saw the smallest reductions 
in general expenditure, and modest cuts to public service and social protection spending over the period 1995-2005.

The priority given to eliminating deficits was highest in countries with high to medium increases in debt (rises of more than 29 percent of GDP) and medium to high inflows and outflows of capital (of more than 46 of GDP) - Finland, Sweden, Canada, Italy, Austria, Germany, Sweden, and Denmark. In these countries, governments cut public service expenditure by 2.7 percent of GDP and overall general spending by 9 percent of GDP. But others such as France and Belgium also enacted austerity measures, either to meet the rules of the Stability and Growth Pact for a maximum overall public debt of 60 percent of GDP, or to maintain a budget surplus and meet the monetary goals set by the European Central Bank, which was concerned with the rising debt levels of individual countries fuelling inflation.

But also common to countries with rising debts and deficits was a concern to redesign their public services and public industries. Governments believed that reshaping their 'micro-economic' contexts - their wage bargaining systems, their public sectors, and their utilities - would impose wage restraint and boost economic growth (OECD 2003, 2005 ; 2009). Adopting a classic liberal view that expenditure on public services was a burden on the productive sectors of the economy, governments sought to make reforms that ensured market forms of coordination would be substituted for public ones wherever possible (OECD 2005; Hall 2003). Only with market competition, it was claimed, would elected officials be able to reign in self-interested administrators and public sector workers and would governments make their public sectors accountable to bottom-lines and their public services more efficient. 
Table 2 Public Sector Modernization 1990-2007

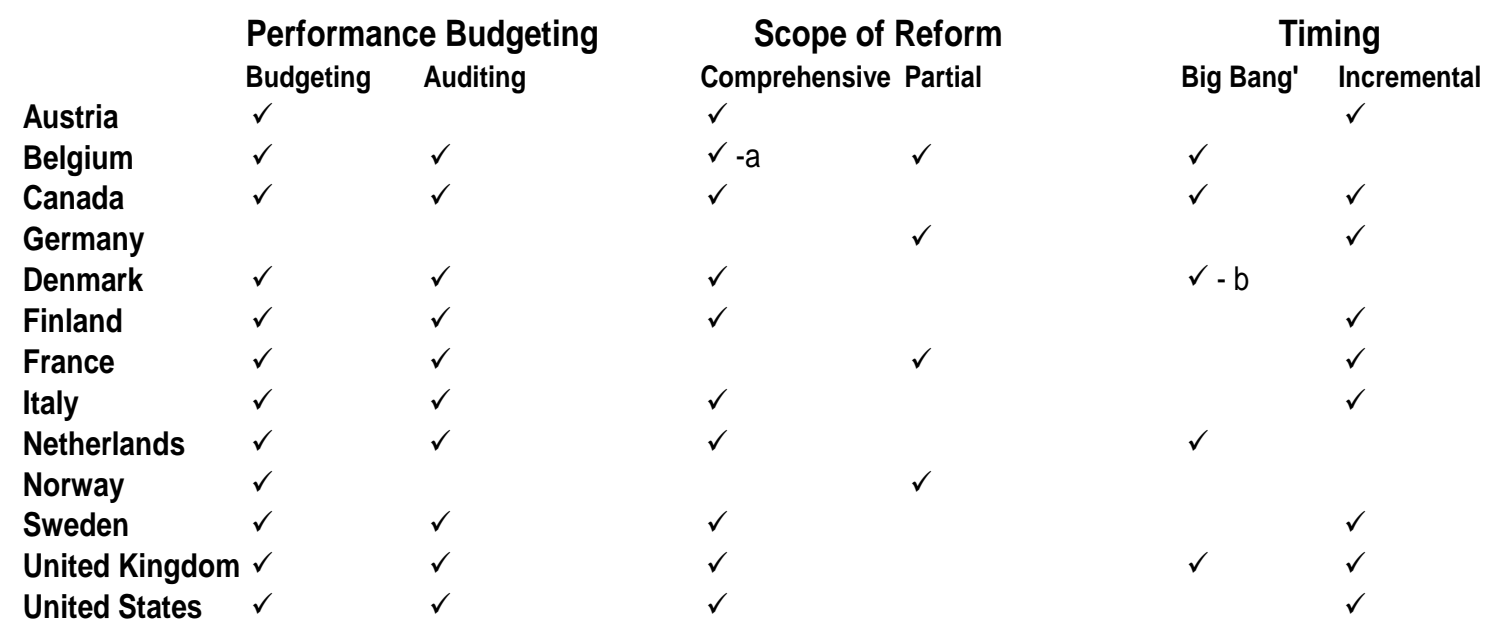

Sources: Pollit and Bouckaert 2004; OECD Performance Budgeting 2007;

OECD Modernising Government 2003;

EIRO 2006 Industrial Relations in the Public Sector

a - Belgian reforms were partial until 'Copernican'

b - Danish reform programme introduced 2007

The first step governments took in enacting changes to reshape the size, functioning, and ownership of their public sectors was in budgeting and administration (Pollit and Bouckaert 2004: 56-102). In countries such as Canada, the United States, Finland, and Belgium, governments declared that reducing or reallocating public expenditure was a 'national' priority, and with central financial officials implemented a top-down expenditure cutting process that continued until the target was met (OECD 2005; Pollit and Bouckaert 2004: 68). Other countries introduced "Top-down" budgeting in order to withdraw or allocate funds to specific activities. And even in countries with very fragmented administrative systems, which were commonly assumed to take longer to enact administrative and financial change, finance ministries and treasury departments were given new roles as the chief overseers for government strategic management in order to enact cuts (OECD 2005: 121).

The next step public officials took to reign in spending was to tie budgeting with planning and output measurement (OECD 2007; OECD 2005). Promising to 'do more with less', governments established performance goals and benchmarks for agencies and sub-national governments. They also transformed programme budgets into block funding, and directed lower level elected officials and managers to 'get results'. In the final stage, most governments instituted compulsory auditing and instructed auditors to find 'waste'. Now, over the past ten years, three-quarters of OECD countries use performance 
budgeting techniques as means of evaluating programs and implementing budgetary decisions and cutbacks (OECD 2005: 18).

Table 2 provides a summary overview of how many countries enacted budgeting, performance, auditing, and major overhauls of their public services and public administration. Until 2005, only France and Norway had yet to undertake major reforms. Belgium and Denmark were slower to reform their public sectors, but by 2007-2008 both countries enacted major administrative and financial overhauls. But with these exceptions, governments had enacted public sector reforms intended to cut costs, overhaul the financial operations, and reform the labour relations of their public sectors.

The priority given to fiscal discipline and budget management was complemented by attempts to reduce government intervention in the economy. Across the OECD, governments restructured their public sector operation through privatization, publicprivate-partnerships (P-3s), and outsourcing (table 3). Whether in North America with market-oriented conservative governments or Western Europe with highly unionized workforces and social democratic governments, state officials sold nationalized industries and utilities. In France in the 1990s, the Socialist government of Lionel Jospin made major changes to France's 'state-led capitalism' by selling government holdings in banking, insurance, electronics, airlines (Levy 2006). Austria sold off banks, oil and gas companies, rail and electricity. Rail and telecommunications operations were privatized in Finland, Denmark, and Sweden. The Scandinavian countries also changed the public ownership of companies with share offerings in everything from postal services to airport traffic management (Pedersini 1999; Hall et al. 2006). As table 3 demonstrates, some of the largest transformations came in the 'state-led' capitalist countries of France, Italy, and Austria. But privatizations were also significant in the liberal market economies of Great Britain and Canada, as well as the coordinated market economies of Sweden and the Netherlands. 
Table 3 Privatisation, PPPs, Outsourcing 1990-2007

\begin{tabular}{|c|c|c|c|c|c|}
\hline \multicolumn{3}{|c|}{ Privatisation (US Millions) } & \multicolumn{2}{|c|}{ P-3s (US Millions) } & \multirow{2}{*}{$\begin{array}{l}\text { Outsourcing } \\
\text { (Percentage of Government Purchases) } \\
2003\end{array}$} \\
\hline & $1990-5$ & 1996-00 & 2001-04 & 2005-07 & \\
\hline Austria & 2,006 & 8,400 & 51.45 & 1097 & 33 \\
\hline Belgium & 4,186 & 4,251 & 1365 & 1006 & 28 \\
\hline Canada & $10,583-a$ & na & 3200 & 705 & 42 \\
\hline Denmark & 1,005 & 4,913 & 406 & 31 & 40 \\
\hline Finland & 1,758 & 12,301 & 1061 & 903 & 45 \\
\hline France & 21,775 & 36,005 & 5828 & 21,674 & na \\
\hline Germany & 1,000 & 14,717 & 462 & 1898 & 43 \\
\hline Italy & 15,870 & 47,603 & 934.5 & 3448 & 25 \\
\hline Netherlands & 9,434 & 2,405 & 1367 & 556 & 45 \\
\hline Norway & 712 & 723 & na & na & 60 \\
\hline Sweden & 3,795 & 11,984 & 880 & 252 & 55 \\
\hline United Kingdom & 51,890 & 12,154 & 22941 & 40114 & 78 \\
\hline United States & $6780-b$ & na & 3129 & na & 62 \\
\hline \multicolumn{6}{|l|}{ * Provisional. } \\
\hline \multirow{2}{*}{\multicolumn{6}{|c|}{$\begin{array}{l}\text { Sources: Financial Market Trends no. 72, OECD, February 1999, pp. 129-145; } \\
\text { International financial services london, 2009. PFl in the UK and PPP in Europe }\end{array}$}} \\
\hline & & & & & \\
\hline \multirow{2}{*}{\multicolumn{6}{|c|}{$\begin{array}{l}\text { Privatization Barometer, Database } 1977 \text { to Present available at: http://www.privatizationbarometer.net/database.php } \\
\text { OECD } 2003\end{array}$}} \\
\hline & & & & & \\
\hline \multicolumn{6}{|c|}{ a- Canada 1990- 2000} \\
\hline b - United States 1 & $1990-2000$ & & & & \\
\hline
\end{tabular}

An equally widespread measure states used to reform their public services were public-private partnerships (P3s) - arrangements whereby the private sector finances, designs, builds, maintains, and operates infrastructure assets traditionally provided by the public sector. Over the past two decade, these were introduced in all OECD countries, and their value has risen sharply since 2000 (table 3). Once commonly used for the financing and maintenance of transportation infrastructure, by the early 2000s, P3s and private financing were used in everything from electrical utilities to schools, hospitals, water and sewage, and local public transport (OECD 2003). With EU support, the number of P3 projects in Western Europe grew from 12,000 in 1987 to 200,000 in 1999 (Shaoul 2003: 156). Available survey evidence indicates that P3s have only grown over the past few years. By 2006 there were over 1,100 projects worth $\$ 509$ billion worldwide, with Europe accounting for 43 percent and nearly half of their dollar value (Hall 2008).

Governments also introduced a number of market structures into the delivery, operation, and management of public services through implementing competitive bidding structures, outsourcing and 'purchaser-provider' splits in order to have employers seek short-term and long-term cost reductions in capital and labour (Table 3) (for overviews see Whitfield 2001; Pollit and Bouckaert 2004). The intent of such 
liberalisation measures was to force providers - whether public or private - to compete with each other for government funding and customers and subsequently increase efficiencies through reductions in labour costs (Flecker et al. 2009; OECD 2005: 132). As table 3 reveals, competitive bidding and outsourcing became widely used practices, as governments introduced competitive tendering and contracting out not only for major utilities such as electricity, telecommunications, and waste collection but for a range of services from blue collar support services (maintenance, cleaning, laundry, food preparation and catering), to professional services such as information technology, to core government functions such as prisons (OECD 2003; 2009).

\section{The Reform of Public Sector Labour Relations}

International literatures have often emphasised that despite the pressures of globalization, differences in welfare state's distributive patterns have remained. Welfare policies have not converged, as increases in inequality continue to be notably larger in the inegalitarian liberal economies than in Northern Europe. Tax and benefit systems, it is also argued, continue to show varying degrees of effectiveness in reducing poverty and redistributing income. But in looking at the effects of fiscal austerity and government reform on public sector labour relations, work, and employment, the impacts were much more uniformly negative.

Price and budget-oriented management led to public officials laying off workers, introducing wage freezes, and increasing job responsibilities. Privatization and marketization gave states and service-employers new levers to enforce wage moderation (Brandt and Schulten 2009; Flecker et al 2009; Whitfield 2001). Across the advanced industrial economies over the last twenty years, what austerity and public sector restructuring have provided for governments was a policy framework to eliminate obstacles in labour market flexibility posed by public sector unions and collective bargaining structures

One of the most significant ways governments attempted to redesign their traditional public sector labour relations was through 'New Public Management', emphasising the decentralisation of public sector bargaining structures, the expansion of individualised pay through bonuses and performance related pay, and the growth of temporary, part-time, and contracted employment (OECD 2008a). Such measures were proposed as a means of making pay and employment conditions more responsive to variations in local market conditions, organisational requirements, and individual employee performance. But their most common results have been the lowering of public sector wages, the extension of working hours, and the institutionalization of cheaper forms of employment throughout the public sector (Bordogna 2008).

'Flexible' bargaining and new corporatist arrangements were key to 'New Public Management', and governments used these to restructure labour relations and weaken 
public sector labour power throughout North America and Western Europe. In Austria, Germany, and Italy, for example, where public employees were long excluded from the right to conclude collective agreements but were protected through legislation, governments rewrote public sector labour relations acts in order to make labour more 'flexible' and deregulate hiring, fire, and pay systems (Bordogna 2008). In these countries, the rewriting of labour legislation allowed governments to employ public sector workers on a private law basis and then subsequently introduce contracting-out, temporary contracts, and more part-time jobs (Brandt and Schulten 2009; Flecker et al 2009).

In contrast, in Canada, Denmark, Belgium, the Netherlands, Norway, and Sweden - where public sector bargaining has long been institutionalized - rather than re-craft public sector labour legislation, governments instead decentralised budgets and reamalgamated regions and municipalities in order to give officials more leeway in contracting out, and to force officials to bargain greater managerial authority over performance-related pay, as well as the hiring and termination of employees (OECD 2005: 167-69). The expectation in these countries was that allowing public managers more control over their own staffing establishment (size, grading and qualifications of workforce), while limiting their budgets, would lead to lower staffing, fewer full-time jobs, and lower labour costs over time. In these ways, governments sought to lower labour costs and reduce benefits through introducing more 'flexible' pay and working conditions.

Governments also sought to lessen public sector bargaining power by decentralising and splitting collective agreements among a number of employers - both private and between public and quasi-public employers. Traditionally, public sector collective bargaining was done in more centralized and coordinated frameworks. This was done to stabilize jobs and wages and ensure continuity in services, and in part to draw workers into labour-intensive jobs.

But as governments have taken on the task of restructuring their public sectors, and bring labour costs in line with those in the private sector, public officials sought to rework their labour relations and collective bargaining systems in a number of ways (Brandt and Schulten 2009: 2-3). Although there are significant national variations in timing and extent, bargaining reforms have often included 'two-tiered' agreements that protect remaining incumbents with good jobs, while allowing newcomers to be employed at poorer wages and working conditions (Bordonga 2008). Also common were new agreements that in the aftermath of privatisation allowed companies to withdraw from central public sector collective agreements, and then either establish their own company agreements, or - in several cases - simply hire workers on an individual contract basis. A further measure that reshaped public sector labour relations was local workplace administrators adopting outsourcing or 'contracting out' as the primary way of lowering public sector labour and benefit costs. In these ways, authorities made it much more 
difficult for unions to 'compress' wages and maintain wages and work conditions that benefitted all workers.

A final approach that governments regularly used to attenuate public sector collective bargaining was by making changes in financial arrangements and to the final employer. In Britain and Canada, for example, both budget and bargaining processes were often separated through 'purchaser-provider' splits that forced local service providers to enact the cuts and restructuring that upper levels of government wanted but were not interested in having to directly bear the political costs. This has led hospitals and regional hospital authorities in both countries to act more like independent businesses and contract out many of their ancillary services, such as laundry, cleaning, and food preparation (Hellowell and Pollock 2007; Lethbridge 2007a). In Sweden, Germany, and Austria, two-level collective bargaining was implemented to allow budget cuts to be negotiated centrally, while private hospitals, private corporations, or regional councils were given the autonomy to cut labour costs by managing hours and introducing more 'flexible' pay and working conditions.

In comparative political economy literature, organized labour in the public sector is commonly considered to wield political clout and maintain standardized wage and work conditions (Beramendi and Cusack 2008; Hou 2009; Mares 2003). But over the past twenty years, the evidence suggests this is no longer the case. Public sector unions have resisted many restructuring measures, sometimes vigorously. But the far more common trend was widening differentiation in bargaining and the growth of low-wage employment. 
Table 4 Public Sector Part-Time and Temporary Employment

(As a Percentage of Total Employment in Sector)

\begin{tabular}{|c|c|c|c|c|c|c|}
\hline & Public Adn & (includ & mil and defense) & Health & id Soci & Vork \\
\hline & 1995 & 2000 & 2005 & 1995 & 2000 & 2005 \\
\hline Austria & 14 & 16 & 21 & 25 & 35 & 39 \\
\hline Belgium & 18 & 25 & 28 & 37 & 47 & 47 \\
\hline Canada & 36 & 37 & 34 & 39 & 52 & 53 \\
\hline Denmark & 24 & 20 & 18 & 35 & 47 & 42 \\
\hline Finland & 17 & 16 & 17 & 31 & 30 & 30 \\
\hline France & 29 & 30 & 29 & 34 & 38 & 38 \\
\hline Germany & 24 & 25 & 28 & 34 & 39 & 46 \\
\hline Italy & 6 & 16 & 14 & 10 & 15 & 23 \\
\hline Netherlands & 30 & 31 & 39 & 68 & 76 & 78 \\
\hline Norway & 22 & 21 & 20 & 43 & 53 & 52 \\
\hline Sweden & 22 & 22 & 27 & 57 & 50 & 55 \\
\hline United Kingdom & 18 & 20 & 21 & 46 & 47 & 40 \\
\hline United States* & 27 & 23 & 24 & 50 & 42 & 43 \\
\hline Mean & 22 & 22 & 24 & 37 & 47 & 43 \\
\hline
\end{tabular}

Sources: Eurostat; Statistics Canada, CANSIM Database; Bureau of Labour Statistics, United States.

* US Figures for Public Administration exclude military and defense; US figures for Health and Social Work include education, and are based on private, public, and not-for profit providers.

As table 4 shows, one of the results of privatization and public sector restructuring was the growth in part-time and temporary public sector employment, which rose in both general public administration and health and social work from 1995-2005. The largest increases in part-time and temporary health and social work came in Austria, Germany, Italy the Netherlands, and Belgium, where private hospitals and hospital networks, and purchaser-provider splits in insurance based systems sought to lower costs. But significant increases in flexible public sector employment were also seen in countries with coordinated bargaining regimes such as Norway and Denmark. In the Netherlands where private insurance and private hospitals worked with unions under flexicurity arrangements, part-time and temporary work continued to rise and now makes up over three-quarters of the labour force in health and social services. In Canada, public hospitals and social service agencies dealt with fiscal constraints by layoffs and increasing part-time employment.

Only in Sweden and Finland was there no significant increase in part-time and temporary employment, as unions accepted layoffs and extended unemployment compensation in place of the expansion of flexible employment. But in Sweden, it is important to note such adjustment occurred with more half of all employment in health 
care and social services already on a part-time or temporary basis, and has recently expanded again with the growth of private hospitals and purchaser-provider systems (Dahlgren 2008). Overall, part-time and temporary employment in health and social work rose rapidly from 37 percent of the workforce to 47 percent in the late 1990s before declining slightly to 43 percent by 2005 .

Fixed-term contacts for manual and blue collar occupations along with upper management contract work also expanded in the late 1990s and early 2000s, reaching 1213 percent in countries such as France (including education and armed forces) and Spain, and at lower job classifications, involved mostly women and young people. Generally, these contractual public servants enjoyed less favourable labour conditions, and for women in particular, who work the majority of public service jobs in health, services, public administration, and finance, this rise in part-time and fixed term contracts in the public sector has meant worsening job security and declines in benefits and long-term job prospects (Bordogna 2008). For instance, in Germany and Finland almost two out of three of all part-time employees in central government are women (62 percent in Germany in 2004; 64 percent in Finland in 2005). In Italy, the Netherlands, Norway and Canada, women represent around 73-80 percent of part-time employees, while the proportion is even higher the UK.

These changes have triggered the rise in low-wage public service work throughout North America and Western Europe. A general trend in many countries was the growth of cleaning, laundry, and food service employees working under part-time, temporary or self-employment contracts. Many of these jobs paid well below employment standards or collective bargained rates, and many of these workers were employed in facilities where staffing levels were between 20 and 30 percent lower (Hall 2008; Hall 2005). Likewise, in the largest public service across all countries - health care - it was common for nurses, nursing assistants, cleaners, and food providers to work for low or inadequate wages. While in long-term care homes, municipal services, and child care, private companies and providers alike attempted to lower costs and prove themselves competitive through worsening contracts, contracting out, and expanding flexible employment (Hellowell and Pollock 2007; Lethbridge 2007). Consequently, the number of low-wage health care workers has grown by more than 50 percent in Germany, Canada, and the United States (Bosch and Kalina 2008; Lethbridge 2007).

Such developments have put the brakes on public sector labour power and undermined the institutional supports for public sector employment. Where once governments used public services and industries alongside regulatory polices to promote income inequality and job security, now public service employment is mirroring trends of private service industries, with rising levels of earnings inequality and volatility, increased part-time and temporary employment, and more low-wage work. Moreover, where in the past unions were able to improve the nature of jobs and the level of wages through collective bargaining, financial globalization and supply side policies have pressured 
states to lower costs and to force through change that weakens labour power and lowers labour cost.

Now part-time and temporary workers are not only more likely to be subject to an average wage penalty of 15 percent throughout the EU, and over 45 percent in other OECD countries (OECD 2006: 169). Part-time and temporary employees are also more likely to receive lower benefits, and in many cases receive no benefits at all. In the United States, for example, 66 percent of part-time and temporary workers are not covered by employer-sponsored health insurance. And in many countries, such as Canada, Germany, Norway, and the United Kingdom, part-time and temporary employees do not qualify for occupational pensions (OECD, 2006: 171). While in others, with earnings-related protection and pension programs, part-time and temporary workers are more likely to receive basic public minimums.

Table 5 Public Sector Employment and Compensation 1980-2005

\begin{tabular}{|c|c|c|c|c|c|c|c|c|c|}
\hline & \multirow{2}{*}{\multicolumn{4}{|c|}{$\begin{array}{l}\text { Public Sector Employment } \\
\text { Percentage of total civilian labour force }\end{array}$}} & \multirow{2}{*}{\multicolumn{5}{|c|}{$\begin{array}{l}\text { Public Sector Compensation } \\
\text { Percentage of GDP }\end{array}$}} \\
\hline & & & & & & & & & \\
\hline & 1980 & 1990 & 2000 & 2005 & $\begin{array}{l}\text { Decline from } \\
\text { Peak }\end{array}$ & & 1990 & 1995 & 2005 \\
\hline Austria & $18.93-b$ & 19.61 & 13.44 & 12.60 & -6.73 & Austria & 11.4 & 12.5 & 9.3 \\
\hline Belgium & 19.17 & 19.99 & $18.56-c$ & 18.5 & -2.54 & Belgium & 10.8 & 11.9 & 12.1 \\
\hline Canada & 19.97 & 20.86 & 19.81 & 17.50 & -2.03 & Canada & 11.4 & 13.7 & 11.4 \\
\hline Denmark & 27.98 & 29.57 & 30.20 & 30.90 & -1.32 & Denmark & 17.5 & 17.1 & 17 \\
\hline Finland & 25.30 & 23.20 & 24.38 & 25.40 & -1.48 & Finland & 13.4 & 15.1 & 13.3 \\
\hline France & 22.39 & 25.45 & 23.45 & 23.50 & -4.24 & France & 13.2 & 13.6 & 13 \\
\hline Germany & 14.81 & 14.93 & 12.30 & 11.30 & -4.60 & Germany & 9.7 & 8.8 & 7.5 \\
\hline Italy & 15.72 & 17.10 & 16.38 & 16.30 & -1.72 & Italy & 11.4 & 11 & 7.2 \\
\hline Netherlands & 15.11 & 12.90 & 11.10 & 11.40 & -5.02 & Netherlands & 9.8 & 10.6 & 9.7 \\
\hline Norway & 24.11 & 28.46 & 31.75 & 29.00 & -0.64 & Norway & 14.3 & 14 & 12.4 \\
\hline Sweden & 35.66 & 36.83 & 31.04 & 29.50 & -6.81 & Sweden & 18.8 & 16.5 & 15.6 \\
\hline United Kingdom & 21.39 & 19.66 & 17.72 & 19.60 & -5.08 & United Kingdom & 11.6 & 10.7 & 11.3 \\
\hline United States & 16.49 & 15.50 & 15.38 & 15.40 & -1.11 & United States & 10.5 & 10.4 & 10 \\
\hline Mean & 21.5 & 21.9 & 20.6 & 20.1 & -3.33 & Mean & 11.4 & 12.8 & 11.5 \\
\hline
\end{tabular}

Sources: OECD Stat. National Figures at a Glance 2009

Pollit and Bouckaert 2004; OECD 2008a; Bordogna 2008

Table 5 makes clear that such public sector restructuring measures resulted in the decline of public sector employment and public sector compensation in a majority of countries. Over the period 1980-2005, public employment declined from peaks in the mid-1990s, and only in a few countries did public employment subsequently experience low levels of growth, most notably Finland and the UK, where employment growth was in part-time and temporary jobs (Table 5). But these small increases in public employment did not return public sector employment to previous levels. 
In contrast to the post-war period where governments expanded public services and industries to boost full-time employment, stabilize earnings, and underwrite national development in the interests of citizens, in the majority of advanced industrial countries examined here, public sector employment went increasingly in reverse as its percentage of total civilian employment fell on average by 3 percent from former peaks. Looking across the period 1980-2005, 8 of the 13 countries saw reductions in public service employment, with only Norway, Denmark, and France seeing increases in the public sector workforce, through primarily part-time and temporary employees. Overall, however, the decline in public sector employment as a percentage of the total civilian labour force was 1.4 percent across the thirteen countries here 1980-2005.

Public sector labour costs were also lowered through privatization, marketization, outsourcing, social pacts, and imposed agreements. As table 5 illustrates, compensation for government employees as a percentage of GDP declined in 9 of thirteen countries 1995-2005. The largest declines came in Austria, Canada, Germany, Italy, and Finland, each with different political economic institutional setups, and there was a 1 percent decline in total compensation in Germany and the Netherlands. Austria reduced public sector wage costs the most, using a combination of privatisation, contracting out, public sector hiring freezes, and the introduction of regularized 'private' collective bargaining, to shrink the public sector work force and enforce wage freezes.

Finland and Norway reduced compensation through coordinated arrangements that froze wages and then tied minimums to the private sector and well below growth and productivity levels. Canada cut employment and compensation through legislated wage freezes, budget reduction, and subsequent provider/employer strategies of layoffs, contracting out, and part-time/flex employment. By contrast, in Great Britain - a 'liberal' regime and the country that has experienced the most widespread attempts at marketization in its public sector - actually saw an increase of .58 percent in compensation 1995-2005 due in part to the increased role of well-paying contracts for consultants and upper management, the increased role of private hospitals, and ongoing attempts to introduce flexible employment in labour markets (Pollock and Leys 2005).

\section{Conclusion}

Over the past ten years, the preponderance of scholarly studies on the welfare state have stressed that there is 'no race to the bottom' - despite globalization and the rise of market oriented politics, it is commonly argued that welfare state retrenchment and public policy reform has been slow and often patterned along partisan and institutional lines. But placing state and public policy reform into a broader political economic context of debt, financialization, and neoliberal shifts in public sector administration and collective bargaining, the evidence strongly supports radical and trade union country 
studies that a number of incremental and cumulative changes have indeed taken place to public sector management and operation in many countries and that regardless of political and institutional setup, many of these have had a negative impact - especially on public services, public service employment, and public sector collective bargaining.

Financial globalization alongside debt management led many governments to emphasise business and economic growth, and among New Right and Third Way Social Democratic parties alike, there is now a widespread consensus that expenditures on public services are a burden on the 'productive' sectors of the economy and that tax cuts and 'new public management' reforms are necessary for growth. Consequently, policies of fiscal austerity, performance budgeting, contracting out, purchaser-provider splits and so on, have been put forward by governments to alter the calculus and priorities of public officials, workers, and interest groups alike. Likewise governments have privatized public assets in order to reduce direct government expenditures, boost financial profits, and lower wage costs.

Government efforts at reforming and restructuring public sector collective bargaining arrangements have similarly enforced wage moderation and worsened jobs, attenuating labour bargaining power through layoffs, early retirement, and the growth of 'flexible employment'. At the same time, declining worker power, weakening class attachment to left political parties, and the rising influence of business on government has significantly transformed government and domestic policy making. Consequently, states have now taken the lead to transform their public sectors along more marketoriented lines.

The results presented here suggest that a major shift has occurred across advanced industrial states, and these appear to have been the result of explicit political design to lower public labour costs and shift service provision to private benefits and private market providers. To further assess to what extent this convergence is occurring, future comparative research on the state, policy, capitalism, and labour would be well served to explore more deeply the impacts of public sector reform on redistribution, jobs, and income security and examine to what degree debt, finance, and public sector bargaining structures have patterned policy and labour market outcomes.

A second important topic for future research on the state and labour is the politics of public sector reform and the reasons for partisan and country differences in the extent of public sector restructuring. Recent literatures on the 'dualisation' of societies have suggested that as the distribution and coverage of social programmes have deteriorated, recent welfare states reforms have perpetuated the structures of advantage and disadvantage in the labour market, and contributed to a politics that enforces divides between 'insiders' and 'outsiders' (Davidsson and Naczyk 2009; Palier and Thelen 2010). The evidence here suggests that public sector 'modernization', 'marketization', and reform is having similar political consequences. 
Policies such as privatization are boosting income inequality through expanding stock markets and financial returns. Likewise, in the case of public sector restructuring, the government introduction of privatization and the restructuring of collective bargaining has given public, private, public-private, and municipal authorities alike the power to pay lower wages and benefits to recent recruits. At the same time, proportional reductions in public employment are lowering the wage share of unskilled workers, and contributing to greater inequality and the expansion of lower-paid private sector jobs. This too is adding to wage and income inequality.

However, rising inequality is known to be a contributing factor to stronger median voter opposition to redistribution (Anderson and Beremendi 2008). Increasing inequality is also associated with lower voter turnouts and to voter demobilization, both of which also are contributing to shifts in party policy preferences.

But to what degree public sector reforms are correlated to recent trends in lower voter turnouts, greater class de- or re-alignment, and the declining support of workers for left and social democratic parties is not known. Over the past decade, across Western Europe, political parties and party systems stopped providing much in the way of support for their public sectors or organized labour in the 1980s and 1990s (Moschonas 2002). Rather Social Democratic parties have regularly resorted as a matter of course to 'Third Way' policies that promoted business and the market while pushing labour to become more flexible and the unemployed more 'active' (Hou 2009). At the same time, no fewer than nine Centre-Right governments came to power in Western Europe over the last ten years, with the majority having populist, tax-cut-oriented, populist Right coalition partners. Given the impacts of public sector restructuring on employment and wages, future research that carefully considers how public sector reform processes are tied to these partisan shifts, the rise in inequality, and policy outcomes may do much to improve our understanding of recent changes in political economy.

A final area of research required will be on the impacts of the current financial crisis on the public sector. Over the course of 2009-2011, governments brought forward a number of 'exit' strategies intended to return the world economy to 'normal' and 'stable' rates of growth (Albo and Evans 2011). With the average debt burden in OECD countries expected to rise above 100 percent of GDP, every government put forward 'exit' strategies that emphasised deficit reduction, tax cuts, and 'structural' reforms to labour market and social policy. 'Fiscal exit strategies' included cutting public expenditures, public sector wage freezes and layoffs, as well as further corporate tax cuts. 'Structural adjustments' central to the governments strategy entailed rolling back public sector pensions, the privatization of further national industries, and further changes to public sector collective bargaining, including withdrawing the right to strike (OECD 2010).

Public sector unions and citizens alike have protested these policies. Around the world, in Britain, France, Greece, Spain, and Wisconsin USA, government austerity policies have brought public sector workers out onto the streets (Evans and Hussey 2011). 
However, unions are finding it difficult to win these battles, and the pressure to rationalise the public sector even further is likely to continue in the coming years.

Comparative scholarship has long assumed that public sector unions are able to mobilize public support and that governments respond to the problems that affect broad majorities. But in the most recent events, such assumptions no longer appear to hold. Governments are going forward with major policy initiatives that support financial and bond markets, and that do much less to reduce inequality through public services and employment. Examining the reasons for this 'backlash' against government and the public sector, in the context of ongoing state support for finance and the wealthy, will do much to improve our understanding of the politics of welfare state change. Such research will also do much to enhance our appraisals of state change and the ongoing fundamental conflicts over income, equality, and jobs.

\section{Bibliography}

Albo, Greg, and Bryan Evans. 2011. "From Rescue Strategies to Exit Strategies: The Struggle over Public Sector Austerity." In Socialist Register 2011: The Crisis This Time, edited by Leo Panitch, Greg Albo and Vivek Chibber, 283-308. Pontypools, Wales: Merlin Press.

Anderson, Christopher J., and Pablo Beramendi. 2008. "Income, Inequality, and Electoral Participation." In Democracy, Inequality and Representation: A Comparative Perspective, edited by Christopher J. Anderson and Pablo Beramendi. New York: Russell Sage Foundation.

Beramendi, Pablo, and Thomas R. Cusack. 2008. "Economic Institutions, Partisanship, and Inequality." In Democracy, Inequality and Representation: A Comparative Perspective, edited by Christopher J. Anderson and Pablo Beramendi. New York: Russell Sage Foundation.

Bordogna, Lorenzo. 2008. "Industrial Relations in the Public Sector", European Industrial Relations Observatory eurofound.europa.eu/eiro/studies/tn0611028s/index.htm.

Bosch, Gerhard, and Thorsten Kalina. 2008. "Low-Wage Work in Germany: An Overview." In Low-Wage Work in Germany, edited by Gerhard Bosch and Claudia Weinkopf. New York: Russell Sage Foundation, 2008. 
Bosch, Gerhard, Steffen Lehndorff, and Jill Rubery. 2009. "European Employment Models in Flux: Pressures for Change and Prospects for Survival and Revitalization." In European Employment Models in Flux: A Comparison of Institutional Change in Nine European Countries, edited by Gerhard Bosch, Steffen Lehndorff and Jill Rubery. New York: Palgrave Macmillan.

Brandt, Torsten, and Thorsten Schulten. 2009. The Impact of Liberalisation and Privatisation on Labour Relations: Pique Policy Paper 2. Vienna: European Commission's 6th Framework Programme.

Castles, Francis G. 2004. The Future of the Welfare State: Crisis Myths and Crisis Realities. New York: Oxford University Press, 2004.

Cusack, Thomas R., Torben Iversen, and Phillip Rehm. 2008. "Economic Shocks, Inequality, and Popular Support for Redistribution." In Democracy, Inequality and Representation: A Comparative Perspective, edited by Christopher J. Anderson and Pablo Beramendi. New York: Russell Sage Foundation.

Dahlgren, Göran. 2008. "Neoliberal Reforms in Swedish Primary Health Care: For Whom and for What Purpose?" International Journal of Health Services 38, no. 4: 697715.

Davidsson, Johan, and Marek Naczyk. 2009. "The Ins and Outs of Dualisation: A Literature $\quad$ Review Available at: socialpolicy.ed.ac.uk/recwowepudisc/working_papers/working_paper_02_09.

Duménil, G., and D. Lévy. 2004. Capital Resurgent: Roots of the Neoliberal Revolution. Cambridge: Harvard University Press.

Economist. 2010. "Growth of the State: Leviathan Stirs Again." The Economist. January 23 (online).

Evans, Bryan and Ian Hussey. 2011. "Special Issue: Resistance to Austerity Politics". Socialist Studies/Etudes Socialistes 7 no. 1.

Flecker, Jörg, Christoph Hermann, Torsten Brandt, Nils Böhlke, and Christer Thörnqvist. 2009. Privatisation of Public Services and the Impact on Quality, Employment, and Productivity (Pique). Vienna: European Commission's 6th Framework Programme. 
Garrett, Geoffrey. 1998. Partisan Politics in the Global Economy. New York: Cambridge University Press.

Glyn, Andrew. 2006. Capitalism Unleashed: Finance Globalization and Welfare. New York: Oxford University Press.

Hall, David. 2005. Evaluating the Impact of Liberalisation on Public Services. London: European Federation of Public Service Unions.

Hall, David. 2008. PPPs in the EU - a Critical Appraisal. London: Public Services International Research Unit.

Hall, David, Jane Lethbridge, Robin de la Motte, Emanuele Lobina, Steve Thomas, and Violeta Corral. 2006. Trade Unions and Reform of Public Utilities: International Perspective. London: Public Services International Research Unit.

Harvey, David. 2006. A Brief History of Neoliberalism. New York: Oxford University Press.

Hellowell, Mark, and Allyson M. Pollock. 2007. Private Finance and Public Deficits: A Report on the Cost of PFI and Its Impact on Health Services in England. The Centre for International Public Health Policy.

Huber, Evelyne, and John D. Stephens. 2001. Development and Crisis of the Welfare State: Parties and Policies in Global Markets. Chicago: University of Chicago Press, 2001.

Huo, Jingjing. 2009. Third Way Reforms: Social Democracy after the Golden Age. New York: Cambridge University Press.

Lee, Cheol-Sung. 2005. " Income Inequality, Democracy, and Public Sector Size." American Sociological Review 70, no. 1: 158-181.

Lethbridge, Jane. 2007. "Who Defines Failures of Health Care Privatization?" In Crisis of Privatisation. Berlin.

Lethbridge, Jane. 2007a. "Changing Care Services and Labour Markets". A Report Commissioned by the European Federation of Public Service Unions (EPSU). 
Public Services International Research Unit. Available at: archive.greensefa.eu/.../220122.jane_lethbridge_changing_care_services_a@en.pdf.

Levy, Jonah D. 2006. The State after Statism: New State Activities in the Age of Liberalization. Cambridge: Harvard University Press.

Leys, Colin. 2003. Market-Driven Politics: Neoliberal Democracy and the Public Interest. New York: Verso.

Mares, Isabela. 2003. The Politics of Social Risk: Business and Welfare State Development. New York: Cambridge University Press.

Mooney, Gerry, and Alex Law. 2007. New Labour/Hard Labour? restructuring and resistance inside the welfare industry. Bristol, UK: The Policy Press.

Moschonas, Gerassimos. 2002. In the Name of Social Democracy: The Great Transformation:1945 to the Present. New York: Verso.

OECD. 2003. Privatising State Owned Enterprises: An Overview of Policies and Practices in Oecd Countries. Paris: OECD.

OECD. 2004. Employment Outlook: Boosting Jobs and Incomes. Paris: OECD.

OECD. 2005. Modernising Government: The Way Forward. Paris: OECD.

OECD. 2006. Employment Outlook: Boosting Jobs and Incomes. Paris: OECD.

OECD. 2007. Performance Budgeting in Oecd Countries. Paris: OECD.

OECD. 2008. Growing Unequal? Income Distribution and Poverty in Oecd Countries. Paris: OECD.

OECD. 2008a. The State of the Public Service. Paris: OECD.

OECD. 2009. Government at a Glance 2009. Paris: OECD.

Palier, Bruno, and Kathleen Thelen. 2010. "Institutionalizing Dualism: Complementarities and Change in France and Germany". Politics and Society 38 no. 1: 119-148. 
Panitch, Leo, and Donald Swartz. 2003. From Consent to Coercion: The Assault on Trade Union Freedoms. Third ed. Aurora, ON: Garamond Press.

Pedersini, Roberto, 1999. "Privatisation and Industrial Relations", European Industrial Relations Observatory. Available at: eurofound.europa.eu/eiro/1999/12/study/TN9912201S.htm.

Pierson, Paul. 2001. The New Politics of the Welfare State. New York: Oxford University Press.

Pollitt, Christopher, and Geert Bouckaert. 2004. Public Management Reform: A Comparative Analysis. Second ed. New York: Oxford University Press.

Pollock, Allyson, Jean Shaoul, and David Rowland. 2001. "Public Services and the Private Sector: A Response to the Ippr". Catalyst Trust. Available at: editiondesign.com/catalyst/pdf/paper1.pdf

Pollock, Allyson M., and Colin Leys. 2005. Nhs Plc: The Privatisation of Our Health Care. New York: Verso.

Pontusson, Jonas. 2005. Inequality and Prosperity: Social Europe Vs. Liberal America. Ithaca, NY: Cornell University Press.

Schmidt, Vivien A. 2008. "European Political Economy: Labour out, State Back in, Firm to the Fore." West European Politics 31: 302-320.

Schulten, Thorsten, Torsten Brandt, and Christoph Hermann. 2008. "Liberalisation and Privatisation of Public Services and Strategic Options for European Trade Unions." Transfer 14, no. 2: 295-311.

Shaoul, Jean. 2003. "Global Capital and Healthcare Reform: The Experience of the Uk." In Restructuring Health Services: Changing Contexts and Comparative Perspectives, edited by Kasturi Sen. London: Zed Books.

Swank, Duane. 2002. Global Capital, Political Institutions, and Policy Change in Developed Welfare States. New York: Cambridge University Press. 
Whitfield, Dexter. 2001. Public Services or Corporate Welfare: Rethinking the Nation State in the Global Economy. Sterling, VA: Pluto Press. 